\author{
YEARBOOK \\ of ANTITRUST \\ and REGULATORY \\ STUDIES \\ www.yars.wz.uw.edu.pl
}
Peer-reviewed scientific periodical, focusing on legal and economic issues of antitrust and regulation. Creative Commons Attribution-No Derivative Works 3.0 Poland License.

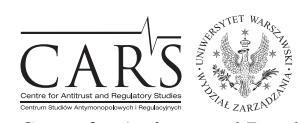

Centre for Antitrust and Regulatory Studies, University of Warsaw, Faculty of Management www.cars.wZ.uw.edu.pl

\title{
Overview of Kazakhstani New Anti-monopoly Regulation
}

\author{
by
}

\author{
Alexander Korobeinikov*
}

\section{CONTENTS}

I. Competition laws and enforcement

II. Restrictive agreements and practices

1. Horizontal agreements

2. Vertical agreements

3. Concerted practices

III. Abuse of dominant market position

IV. Control over economic concentration

V. Protection from unfair competition

VI. Liability for violating competition laws

\section{Abstract}

The main statute governing competition in Kazakhstan is the Entrepreneurial Code, first adopted in October 2015. Section 4 of the Code in particular is aimed at the protection of competition in Kazakhstan. It primarily deals with anticompetitive agreements and conduct, provides for a control system over economic concentrations, and regulates anti-monopoly investigations. The anti-monopoly provisions of the Code are enforced by the Committee on the Regulation of Natural Monopolies and Protection of Competition within the Ministry of the National Economy of the Republic of Kazakhstan and its regional departments located in each Kazakhstani region and its two main cities (Almaty and Astana). The

* Lawyer, Baker \& McKenzie - CIS Ltd, Almaty, Kazakhstan; Alexander.Korobeinikov@ bakermckenzie.com. Article received: 22 November 2016; accepted: 2 December 2016. It is based on Kazakhstani legislation which is in force as of 22 November 2016.

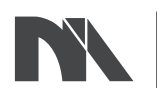

Ministry of Science and Higher Education

Republic of Poland
The creation of the English-language version of these publications is financed in the framework of contract No. 768/P-DUN/2016 by the Ministry of Science and Higher Education committed to activities aimed at the promotion of education. 
Committee has a broad range of powers and duties ranging from investigating anticompetitive conduct and imposing administrative sanctions to regulating natural monopolies. The Code generally prohibits horizontal and vertical agreements and concerted actions that lead (or can lead) to restriction of competition, albeit it also provides certain exemptions. The Code includes an exhaustive list of conduct which is prohibited for dominant entities. The Anti-monopoly Committee exercises control over economic concentrations by overseeing mergers, consolidations, acquisitions and certain other transactions.

\section{Résumé}

La loi principale régissant la concurrence au Kazakhstan est le Code de l'entreprise, adoptée en octobre 2015. Notamment la section 4 du Code de l'entreprise vise à protéger la concurrence au Kazakhstan. Elle stipule des dispositions concernant des ententes anticoncurrentiels et des pratiques concertées, elle prévoit un système de contrôle des concentrations et réglemente des enquêtes concernant les violations du droit de la concurrence. Les dispositions du Code de l'entreprise concernant la concurrence sont appliquées par le Comité sur la réglementation des monopoles et la protection de la concurrence, au sein du Ministère de l'économie nationale de la République du Kazakhstan et dans ses départements régionaux situés dans chaque région du Kazakhstan et dans ses deux principales villes (Almaty et Astana). Le Comité possède de multiples prérogatives et de fonctions allant de l'examen de comportement anticoncurrentielle et l'imposition de sanctions administratives à la réglementation des monopoles naturels. Le Code interdit généralement les accords horizontaux et verticaux ou les actions concertées qui conduisent (ou peuvent conduire) à la restriction de la concurrence, mais il prévoit aussi certaines exemptions. Le Code contient une liste exhaustive de comportements interdits aux entités dominantes. Le contrôle de concentrations est exercé par le Comité anti monopole et il s'agit de contrôle des fusions, des regroupements, des acquisitions et des certaines autres transactions.

Key words: Kazakhstan; antitrust law; Entrepreneurial Code; anti-competitive agreements; economic concentration; restrictive agreements; dominant market position; unfair competition; violating competition laws.

JEL: K21 


\section{Competition laws and enforcement}

The main statute governing competition in Kazakhstan is the Entrepreneurial Code $^{1}$ (hereinafter, the Code), first adopted in October 2015. Moreover, several other acts ${ }^{2}$ were adopted to add detail to the main requirements set forth in the Code.

Section 4 of the Code in particular is aimed at the protection of competition in Kazakhstan. It primarily deals with anti-competitive agreements and conduct, provides for a control system over economic concentrations and regulates anti-monopoly investigations.

The Code uses the principle of extraterritoriality of Kazakhstani antimonopoly rules. This means that the actions of companies and individuals conducted outside Kazakhstan are subject to the anti-monopoly provisions of the Code if (i) these actions directly or indirectly affect companies, their shares or their assets in Kazakhstan, or (ii) these actions result in a restriction of competition in Kazakhstan.

The anti-monopoly provisions of the Code are enforced by the Committee on the Regulation of Natural Monopolies and Protection of Competition within the Ministry of the National Economy of the Republic of Kazakhstan (hereinafter, the Committee), as well as its regional departments in each Kazakhstani region and its two main cities (Almaty and Astana).

The Committee has a broad range of powers and duties ranging from investigating anti-competitive conduct and imposing administrative sanctions to regulating natural monopolies.

\section{Restrictive agreements and practices}

The Code generally prohibits horizontal and vertical agreements and concerted actions that lead (or can lead) to the restriction of competition, albeit it also provides certain exemptions.

\section{Horizontal agreements}

Certain types of horizontal agreements are classified as cartels and are presumed to pose the greatest threat to competition. Therefore, cartels cannot benefit from an exemption. They include agreements aimed at:

\footnotetext{
1 http://cis-legislation.com/document.fwx?rgn=80123 (22.11.2016).

2 http://adilet.zan.kz/eng/docs/Z080000112 (22.11.2016).
} 
- establishing prices (tariffs), discounts, surcharges (add-on payments) and mark-ups;

- increasing, reducing or supporting prices at auctions;

- dividing a market according to a territorial principle, according to sales volume or purchase volume, or providing for a product range of goods to be sold according to the composition of sellers or buyers (customers);

- reducing or ceasing the production of goods;

- forming block agreements with specific sellers or buyers (customers); and

- boycotting certain suppliers or customers.

The presumption that the above types of horizontal agreements pose the greatest threat to competition does not apply to intra-group agreements.

\section{Vertical agreements}

Agreements between business actors acting at different levels of the supply and production chains (e.g. distribution agreements) are prohibited if they may restrict competition. The following vertical agreements are specifically prohibited by the Code:

- agreements regulating product resale prices by establishing fixed prices (an exception is made for agreements that set maximum prices);

- agreements prohibiting a buyer from selling goods of the seller's competitor (an exception is made for arrangements involving the use of trademarks or similar arrangements); and

- agreements prohibiting a seller from selling goods to the buyer's competitor.

Examples of other anti-competitive agreements prohibited by the Kazakhstani anti-monopoly rules include agreements that:

- establish or maintain discriminating terms for equivalent agreements with other market participants, including the establishment of coordinated terms for the purchase and/or sale of goods;

- distort the results of bidding, auctions and tenders by violating established procedures, including dividing them up by lots;

- unjustifiably restrict or terminate sales;

- restrict access to a goods market or exclude other market participants from a market (either sellers of certain goods or their buyers); or

- conclude agreements that place additional obligations on counterparties that, according to standard business practices, do not relate to the subject matter of these agreements (including unjustified requirements 
to transfer financial funds or other property, as well as property or nonproperty rights).

Exceptions can include (although these exceptions do not apply to every kind of agreement):

- agreements within a group of entities;

- agreements on the use or transfer of intellectual property (hereinafter, IP) rights; ${ }^{3}$

- vertical agreements that are concession agreements or comprehensive business licences (franchising);

- agreements in which the total market share of a market participant in the market for goods does not exceed 20\%; and

- agreements where the market participants have proven that the agreements have resulted or could result in:

(i) improvements in the manufacturing or sales of goods, stimulation of technical or economic progress, or an increase in the competitiveness of the manufactured goods in the world market; or

(ii) a benefit to consumers that is equal to or greater than the benefit to the parties executing the agreement.

\section{Concerted practices}

The prohibition under the Code applies equally to concerted practices between competitors that lead to a restriction of competition. Concerted practices are situations of informal co-operation, such as parallel behaviour on a market between parties without any formal agreement, or a decision that meets the following criteria:

(i) the outcome of the action is in the interest of each market player;

(ii) each market player is aware of the actions of other market players;

(iii) the actions of each market player are based on the actions of other market players and do not result from circumstances equally affecting all market players; and

(iv) the aggregate market share of market players is equal to or exceeds $35 \%$.

Certain concerted actions may be permitted, provided they are aimed at implementing advanced technologies or developing small and medium businesses.

3 Please note that the Kazakhstani Government is considering amendments to the Kazakhstani anti-monopoly law which, among other things, are aimed at restricting the application of the IP exemption. The main reason for the Government's decision to adopt these amendments is the fact that market players often abuse their right to use this exemption. 


\section{Abuse of dominant market position}

The Code defines a dominant market position as the ability of one or several business players to control the relevant market. The following entities are considered to be dominant: a market player holding a 50\% or more market share; and jointly dominant entities where three or four business entities have market shares of $50 \%$ or $70 \%$ respectively and none of them have a market share of less than $15 \%$. In addition, an entity holding a 35\%-50\% market may be deemed dominant based on criteria such as market share, market power and barriers to market entry.

The Code includes a list of conduct which is considered as abuse of a dominant market position. Examples include the following types of prohibited conduct:

- establishing and maintaining monopolistically high (low) or monopsony low prices;

- setting different prices or different conditions to equivalent contracts with market entities without a legitimate reason;

- setting limitations on the resale of goods purchased from the dominant entity on the grounds of location, range of customers, terms and conditions of purchase, quantity or price;

- concluding agreements that place additional obligations on counterparties that, according to standard business practices, do not relate to the subject matter of these agreements;

- without a legitimate reason, refusing to deal with certain market entities;

- conditioning the supply of goods by setting restrictions on the purchase of goods produced or sold by competitors; and

- without a legitimate reason, reducing production and/or supply volumes or terminating the production and/or supply of goods for which there is demand, while being able to produce or supply such goods.

\section{Control over economic concentration}

The Anti-monopoly Committee exercises control over economic concentration by overseeing mergers, consolidations, acquisitions and certain other transactions. If the relevant transaction achieves the thresholds established by the Code, it will be subject to pre-approval or post-transaction notification formalities. 
Particularly, the following actions require pre-approval from the antimonopoly authorities:

- reorganisation of a company by means of a merger or takeover;

- acquisition of more than $50 \%$ of the shares in a company; and

- acquisition a company's assets, the value of which is more than $10 \%$ of the total net book value of the company's assets.

Achievement of rights to influence a company's management decisions by executing the relevant arrangements or by being elected/appointed as a member of a company's management body only requires post-transaction notification.

Failure to obtain such approval or to notify may result in the unwinding of the relevant transaction.

A foreign-to-foreign transaction (e.g. an acquisition of shares in a foreign entity that takes places outside of Kazakhstan) is subject to Kazakhstani merger clearance if:

- it directly or indirectly involves/affects production fixed assets or intangible assets located in Kazakhstan, or shares in Kazakhstani market entities, or property rights in respect of Kazakhstani legal entities; or

- it adversely affects competition in Kazakhstan.

\section{Protection from unfair competition}

Under the Code, the following activities constitute unfair competition:

- use of trademarks or packaging without authorisation;

- use of goods of another manufacturer without authorisation;

- copying an article's appearance;

- discrediting a competitor;

- advertising flagrantly false, improper or unreliable information;

- demanding the sale of goods in compulsory assortment;

- a call to boycott a seller (supplier);

- a call to discriminate against a buyer (supplier);

- a call to break a contract with a competitor;

- bribing a seller's (supplier's) employee;

- bribing a buyer's employee; and

- use of trade secrets without authorisation. 


\section{Liability for violating competition laws}

Violations of anti-monopoly legislation (including acts of unfair competition, failure to obtain approval of a merger when required, failure to obey the orders of the competition authority or monopolistic activity) may entail civil, administrative and criminal sanctions.

Abuse of dominance and anti-competitive agreements or actions are punishable by fines of up to $10 \%$ of the income received by a relevant market player from the illegal activity in addition to the potential confiscation of all such income.

Fines may be reduced in certain circumstances, such as when an offender has informed the Committee of the offence itself and cooperated with the investigations.

In addition to that, the competition authority may seek the invalidation of anti-competitive transactions in the framework of civil court actions.

Finally, if anti-competitive actions/arrangements result in significant losses for other market players and/or customers, the management of companies which breach anti-monopoly rules may be sentenced by criminal courts to up to 6 years of imprisonment. 